\title{
Effects of Two Modes of Active Learning Strategies on School Age Childrens' Civic Competence in Leadership Value Concepts in Social Studies and Civic Education
}

\author{
A.F. Ayo - Vaughan \\ Department of Curriculum and Instruction, Federal College of Education (Technical) \\ Asaba; oluwanikanlomola@gmail.com \\ P. A. Amosun \\ Department of Teacher Education, University of Ibadan, Ibadan; amosun2002@gmail.com
}

Doi:10.5901/jesr.2016.v6n2p213

\begin{abstract}
The civic competence of school age children has become questionable as a result of inappropriate leadership value manifestations. Active learning strategies have been suggested to serve as a panacea to this problem. However, the use of these strategies in the social studies and civic education classrooms are very rare in Nigerian secondary schools. This study, therefore, determined the effects of two modes of active learning strategies (case study and puzzle-based games) on school age children civic competence in leadership value concepts in social studies and civic education in Delta State, Nigeria. The study adopted the pre-test-post-test, control group quasi-experimental design. Junior secondary students in Delta state made up the population of the study. Multi-stage and simple random sampling techniques were employed in arriving at the sample. A total of two hundred and sixty - five students made up the study sample. Civic Competence Scale ( $r=0.68)$, Conventional Lecture Method Guide ( $r=0.78)$, Case Study Strategy Guide $(r=0.60)$ and Puzzle-Based Instructional Games Strategy Guide $(r=0.67)$ were used as instruments for data collection. Data were analysed using Analysis of Covariance, Estimated Marginal Mean and Scheffé Pair-wise Comparism at 0.05 level of significance. The findings of the study showed that though there is a significant main effect of treatment on school age childrens' civic competence, the puzzle-based games strategy enhanced their civic competence better than the case study strategy. Consistent exploration of these strategies in the social studies and civic education classrooms in Nigerian schools was recommended.
\end{abstract}

Keywords: Civic competence, Active learning strategy, Case Study, Puzzle-Based Games, Leadership value concepts, School age children

\section{Introduction}

The art of developing civic competent leaders is a process which requires careful acquisition of specific values which are taught not caught. The word leadership itself is derived from a root word which is similar in meaning to the Latin word (educere) from which the word education is derived and both mean to "draw out" or "lead forth". Similarly, civic competence which connotes acquisition of knowledge, skills, attitudes and values needed to enable an individual become an active citizen makes it possible to say that a strong link exists between leadership values and civic competence. Nonetheless, maintenance of appropriate values has always been instrumental to the development of civic competent leaders in any society.

Kouzes and Posner (2002) found the following to be leadership values expected of leaders as viewed by respondents selected from six continents: being honest, being forward-looking, being competent, being inspiring, being intelligent, being fair-minded, being broad-minded, being supportive, being straightforward, being dependable, being cooperative, being determined, being imaginative, being ambitious, being courageous, being caring, being mature, being loyal, being self-controlled, and being independent. Damekaa (2010) in his study on leadership and governance confirmed these values as essential leadership traits. However, Amosun and Ayo - Vaughan (2011) have pointed out that a good number of undergraduates who are well informed on issues of governance perceive of the state of leadership values in Nigeria as being weak and below standard thus the poor level of civic competence displayed by leaders.

Notably, Bolarin (2005) pointed out that societal values such as belief in God, detesting laziness, dignity of labour, respect for parents and elders, hospitality, integrity, public spiritedness, respect for authority, hardwork, truthfulness and honesty have started getting eroded. Nnachi (2006) also noted that students especially the boys engage in political 
thuggery, election manipulation and rigging, robbery and acts of vandalism in respect of public properties. Majority of secondary school students' as reported by Alutu and Aluede (2006) believe that cheating in Nigeria has become a common occurrence at examinations. While, Esen (1970); Fayombo and Aremu (2000); Okorodudu and Okorodudu (2004); Kobiowu (2006); Enakpoya (2009) and Afolayan and Afolayan (2010) identified a prevalent practice of drug abuse among post primary school students, teenagers and even adults in the Nigerian community, Anochie and Ikpene (2001) revealed that female secondary school students in Port-Harcourt, Nigeria have high incidence of sexual intercourse and majority of students between the ages of 12 to 15 frequently engaged in sex and had aborted severally.

The findings above indicate that the values of self control, care, maturity, loyalty, independent mindedness, honesty, integrity, self-control, positive role model and independence which are leadership oriented are lacking among secondary school students. This is also in agreement with Enu and Esu (2011) that core values of Nigeria especially that of leadership over the years have been weakened and need be strengthened. Therefore, today's children definitely cannot be the kind of leaders expected in future.

\section{Literature Review}

The advent of western education which brought about the existence of schools as formal institutions for transmitting societal values and compartmentalization of subjects in the teaching of such values, led to the emergence of subjects like social studies. National Council for Social Studies (NCSS, 2010) defined social studies as the integrated study of the social sciences and humanities to promote civic competence. The NCSS stated further that the primary purpose of social studies is to help young people develop the ability to make informed and reasoned decisions for the public good as citizens of a culturally diverse, democratic society in an interdependent world. Adesina and Adeyemi (2007) also linked the definition of social studies to that subject whose goal has traditionally been to educate the young to become effective citizens.

In this regard, Adaralegbe (1980) maintained that the objectives of social studies teaching reveals that though it intends to impart knowledge, the core of its existence remains instilling values that make an individual a competent citizen thereby maintaining a sustainable society. Social studies teaching thus seeks to emphasize how knowledge acquired by an individual serves as the foundation for his/her all - round productive contributions to the society. This view was emphasized by Mansaray (1991). To strengthen the achievement of social studies objectives, the Federal Government of Nigeria introduced the Civic Education curriculum in the year 2007. The curriculum was designed to address young Nigerians in their formative years with a view to addressing issues that are important to developing them into competent citizens. The idea here is that a combination of civic education and social studies teaching in schools would help achieve the objective of developing civic competent citizens.

Notwithstanding the importance of the subjects' social studies and civic education, their objectives did not seem to be effectively realized as attitudinal flaws which diminish civic competence have been observed in Nigerian schools and the society at large. In this regard, Kolawole (2005) indicated that the problem of attitudinal flaws may not be unconnected with the fact that the Nigerian educational system has proved incapable of tackling the negative values in the society. However, Enu and Esu (2011) and the South African Department of Education (2001) maintained that schools remain best suited to teach appropriate values transmission but the way (methodology) in which they teach these values could be responsible for observed value lapses. Similarly, Waghid (2004) submitted that the virtues of responsible citizenship can best be learned in schools.

Ogunsanya (1984) had earlier suggested at the inception of social studies that it is only when more than one strategy is employed that teaching and learning of social studies can involve all the senses which will result in making learning more permanent, recall much easier and teaching more effective. Furthermore, whichever strategy or combination of strategies a teacher uses, Ogunsanya maintained that the teacher should always ensure active student involvement and participation otherwise teaching may take place but learning will suffer. This view was supported by Ajiboye (2004) who also maintained that social studies is different from other disciplines of the social sciences in structure and content, purpose and methods of teaching. Consequently, the social studies and civic education teachers can no longer rely solely on the use of memorization, direct formal instruction, reading, recitation and other similar strategies in the teaching and learning of value concepts.

Despite scholarly findings on modern trends in teaching, Adesoji (2004) noted that teachers still make popular use of teacher centered strategies like lecture method for reasons such as lack of infrastructural facilities, overloaded curriculum and lack of training programmes/workshops. These reasons Adesoji (2004) maintained are responsible for teachers' reluctance to explore other teaching strategies asides the traditional lecture method. This position has not 
changed since then. Studies carried out on effective strategies to be used have revealed that purposeful teacher-training alongside effective teaching strategies for values education concepts must be prioritized (Jansen and Christie, 1999). This implies that the selection of the most effective teaching strategies in a teaching - learning process determines the level of students' learning outcomes. These submissions agree with Ogunsanya (1984) that the assessment of the most effective strategies for teaching values education concepts in any meaningful way can only be effectively achieved when a combination of active learning strategies are used.

Nevertheless, suggested active learning strategies are uncommon in the social studies and civic education classrooms in Nigeria. For instance, very few studies investigated the effect of some active learning strategies on students' civic competence and these were on concepts not related to leadership values (Adeyemi and Ajibade, 2012; Cam and Geban 2011; and Sendur, 2012). Majority of studies carried out on leadership values have examined areas such as expected leadership values (Kouzes and Posner, 2002); leadership redefinition (Lambert, 2003); leadership and governance (Mazi, 2010; Oni, 2006; Fagbadebo, 2007); responsible leadership (Oyeniran, 2010; Pless and Maak, 2009). But these studies did not dwell on the investigation of the effects of teaching strategies. Similarly, only a few studies (for example, Banerji and Krishnan, 2000; Krishnan, 2001; Popper, Mayseless and Castelnovo, 2000; Sosik, 2005; Turner, Barling, Epitropaki, Butcher and Milner, 2002) placed emphasis on the role of values, ethics or moral development on leadership. The findings of these reports provided sufficient rationale for the researchers to examine the effects of active learning strategies such as case study and puzzle based instructional games on secondary school students' civic competence in leadership value concepts in social studies and civic education.

The case study strategy (also known as case based learning or case studies) is an active learning strategy that involves the use of narratives developed to provide authentic learning for students. It is often associated with medicine, law, psychology and business education but can be used in any discipline to explore how issues and principles learned in the classroom translate in real world situations (Aaron, 2006). Davis and Willock (2003) also defined case study as student centered activities based on topics that demonstrate theoretical concepts in an applied setting. In agreement, Inez (2009) stated that the case study teaching strategy is significant because it promotes "study of practice" perspective via case based learning. Aaron (2006) stated further that humans' reason based on previous similar experiences (case based) rather than having an in-depth understanding of the problem (concept-based).

In an experimental study investigating the effects of case study on students' learning outcomes in cellular respiration, Rybarczy, Baines, McVey, Thompson and Wilkins (2007) found out that students who were exposed to the case study strategy manifested a significantly greater achievement, and more importantly demonstrated a better use of higher-order thinking skills (competence) than their counterparts not exposed to the strategy. Nevertheless, the researchers stated that more rigorous testing is needed. These positive effects that case study has on students learning outcomes made Lombardi (2007) to state that the use of case study helps provide students with authentic learning situations that aid transfer of learning. Furthermore, when students engage in analyses and discussion, they get a better understanding of difficult or complicated concepts and analyze them more effectively. Amosun (2002) similarly noted that the success of students who learn in groups over their counterparts exposed to teacher-centred methods of learning may not be unconnected with the level of their participation in the learning process.

Teaching value concepts in social studies and civic education is quite a difficult task because values are intrinsic in nature. Since social studies and civic education seeks to produce functional and competent citizens which can only be achieved through internalizing appropriate values, strategies used to teach must incorporate elements of active participation, cooperation, collaboration, interactivity and interest from the learner. These conditions make the use of instructional games relevant. Thus, to Agwagah (2001), a game is a type of play that follows a set of rules, aims at a definite goal or outcome and involves competition against other players or against barriers imposed by nature of the game. It is a situation in which an individual or a team of people play or compete against one another with an agreed upon set of rules, a limited time and a means of scoring, winning or losing actions (Clegg, 1991).

Adedoja and Fakokunde (2010) in agreement with Greenblat (1981) noted that asides the capability of instructional games to facilitate learning, it is also capable of inculcating the right skills, attitudes and values in young one which are an essential ingredient in developing civic competence. Nevertheless, there is now a growing variety of instructional board games which covers a large spectrum of the social studies curriculum (Adeyemi and Ajibade, 2011). These games can also be applied to the civic education curriculum. Puzzle games are one of such growing variety of instructional board games.

The puzzle game stands out as a classroom tool and have been used successfully in many different disciplines (Childers, 1996), showing their versatility and flexibility. They are also a useful tool as most students are already familiar with them, which reduces the need to explain directions and saving class time (Crossman and Crossman, 1983; 
Weisskirch, 2006). In a large scale quantitative study that involved 1102 teens between the ages of 12 -17 on teen video game play, video gaming and civic engagement, sponsored by Pew Internet and American Life Project and MacArthur Foundations, Lenhart, Kahne, Middaugh, Macgill, Evans and Vitak (2008) found out that the quantity of games played was not strongly or consistently related to students' civic outcomes, but some particular qualities of playing games had strong and consistent positive relationship to a range of students' civic outcomes. Puzzle games ranked second on the chart of most frequent video games played by these students.

Similarly, in a quasi experimental study which involved 68 middle school students in America, carried out by Pagnotti (2012) to determine the effects of civics based video games on students' civic engagement, the researcher found out that in the overall, civic based video games did not enhance civic engagement but there was a significant difference in the mean changes in civic engagement scores of those students who spent more time playing civic based video games. Pagnotti (2012) found out that there were concrete differences in the civic engagement of middle school students across different grade levels in response to civic based video games provided. This implies that, being exposed to civic based video games had a greater effect on students at higher grade levels than lower grade levels and also those students who spent more time playing the games. Arising from this background information, this study was therefore set out to determine the effects of two modes of active learning strategies on school age children civic competence in leadership value concepts in social studies and civic education.

\section{Statement of the Problem}

Leadership competence in Nigeria today is questionable because it is replete with attitudinal flaws which have also been observed to exist at a high rate among school age children. Since leadership competences have been found to be necessary for making informed and reasoned decisions, the stability of the attitude of a leader is important. The reason for these flaws has been partly adduced by several studies to the consistent use of the conventional lecture method in teaching leadership value concepts, while the use of active learning strategies such as case studies and puzzle based instructional games which have been suggested is neglected. Though attempts have been made to curtail attitudinal flaws, these attempts placed little or no emphasis on active learner participation or the use of active learning strategies and have somewhat been unable to offer students' the opportunity to develop civic competences necessary for leadership. Therefore, this study determined the effects of two modes of active learning strategies on school age children civic competence in leadership value concepts in social studies and civic education.

\section{Hypothesis}

$\mathrm{H}_{0}$ : There is no significant main effect of treatment on students' Civic competence in leadership values in social studies and civic education.

\section{Methods}

This study adopted the pretest - posttest, control group, quasi experimental design to determine the effects of two modes of active learning strategies on school age children civic competence in leadership value concepts in social studies and civic education. The researcher exposed subjects in experimental group 1 to leadership value concepts using case study strategy (Treatment 1). The same content was selected and taught for experimental group 2 using puzzle - based games strategy (Treatment 2)

The South-South zone of Nigeria and Delta State in particular was selected for this study based on judgmental sampling technique in order to reflect a representative sample of Nigerian states plagued with attitudinal flaws by young ones who are deemed leaders of tomorrow. Multi Stage sampling technique was used to split Asaba into three clusters based on their senatorial districts from which Delta North senatorial district was randomly selected via ballot. Delta North senatorial district was then split into seven clusters based on the metropolitan nature of its towns. Three towns comprising of Asaba, Agbor and Ogwashi - Uku were then randomly selected via ballot. Six secondary schools were then purposively selected from these towns based on certain criteria listed below and randomly assigned to the experimental and control groups for the purpose of this study.

The criteria for selecting the schools were:

1. Schools in which all topics to be covered in this study have not been taught.

2. Schools wherein the principals and teachers agreed to participate in the research endeavour. 
3. Schools that have qualified social studies teachers with a minimum of Nigeria Certificate in Education (NCE).

4. Schools where the social studies and civic education curricula are implemented.

Intact JSS 2 classes sample were selected in each of the six secondary schools that permitted their students' to partake in the study and a total of two hundred and sixty-five (265) students participated. Junior Secondary 2 (JS2) students were purposively selected to make up the target population of the study because the concepts to be treated have been fixed in the official curriculum to be taught at this level. Also, the students were not preparing for the external Junior Secondary School Examination, and as such they were much more available to participate in the study. In addition to these, the students are at the formational stage of values development and participating in this study would help define their leadership values orientation.

The main instrument used for data collection was the Civic Competence Scale (CCS) and the treatment packages of Case Study Strategy Guide (CSSG); Puzzle Based Instructional Games Strategy Guide (PBIGSG) and Conventional (Class) Lecture Method Guide (CLMG). The CCS was a scale of measure adapted from the Civic Competence Composite Indicator 1 \& 2 of Bryony, Ernesto, Daniel and Carolyn $(2008,2011)$ and Georgia's Behavioural Competency Framework of Hecht (2008). The CCCI $1 \& 2$ are outcomes of a research effort on measuring civic competence in Europe sponsored by the European Union (EU) and conducted by the European Commission's Joint Research Centre. The scale is built using a framework comprised of 4 dimensions which are knowledge, skills, attitude and values. The Georgia's Behavioural Competency Framework is built around behavioural indicators of expected leadership behaviours.

The CCS thus consisted of two sections. Section A covered data on students' demographic variables of name of school, sex and family structure. Section B consisted of a total of 30 items meant to measure respondents' civic competence levels that are intended to be enhanced after being exposed to the treatment. The modified Likert four point scale of strongly agree, agree, disagree and strongly disagree and a combination of the rubric response of very important, sometimes important, sometimes unimportant and not important alongside very well, well, moderately well, little and not at all was used for different sections of the scale which covered the four dimensions that make up civic competence. The 30 items drawn were subjected to peer and expert review to determine its face and content validity and appropriate modifications were made after experts in the Department of Teacher Education reviewed it. The items were also tried out on a sample of JS 2 students that were not part of the main study and a reliability coefficient of 0.68 was obtained after subjecting the instrument to Cronbach's Alpha analysis.

The CSSG was designed by the researcher to guide teachers in experimental group 1. This was done to ensure uniformity in the research process. The CSSG was prepared on each of the concepts selected for the study. The instrument was validated by experts in the field of social studies from the social studies unit of the Department of Teacher Education, University of Ibadan to determine the internal consistency, relevance, recency of cases, stimulating effect and appropriateness of the instrument. The reliability of the instrument was tested using Cronbach's Alpha analysis and a reliability coefficient of 0.60 was obtained.

The PBIGSG was designed by the researcher to guide teachers in experimental group 2. This was done to ensure uniformity in the research process. The PBIGSG was prepared on each of the concepts selected for the study. Two Puzzle - Based Instructional Games packages were applied in this study. These are crossword and scrambled words plus extra letters puzzles. The initial game prototype was tried out on a small group of 10 students to examine its flexibility, usage and validity. The results enabled decisions making for modification where necessary and a re-trial of the modified game on an intact class of 37 students in JS 2, Abadina College. Finally, the instrument was given to fifteen experts in the field of Educational Technology and Social Studies to score based on a 4 point Likert rating scale and a reliability coefficient of 0.67 was obtained using Cronbach's Alpha analysis.

The CLMG was designed by the researcher to guide teachers in the control group. This was done to ensure uniformity in the research process. The CLMG was prepared on each of the concepts selected for the study. The instrument was subjected to peer and expert review to determine content appropriateness and consistency with the target learners and curriculum objectives. It was also subjected to Scott Pi's inter-rater index for reliability and a coefficient of 0.78 was obtained.

\section{Research Procedures}

\subsection{Pre-Experimental Activities}

This study covered a period of ten weeks. The stages involved in carrying out the research are explained below. The researchers selected and trained three undergraduates from the Federal College of Education (Technical) Asaba as 
research assistants. The research assistants were trained on the nature and purpose of the new teaching strategies. Preceding this, the researchers visited the schools that were to be selected for the study to seek the principal's permission. One intact class was randomly selected from each participating school. This was followed by the recruitment and orientation of the teachers that were used in the study for both control and experimental schools.

\subsection{Recruitment and Orientation of Participating Teachers}

Participating teachers were trained and those who performed satisfactorily according to the Teacher Training Evaluation Sheet used for the study for evaluating their performance were selected. Nevertheless, the teaching subject (social studies and civic education) of the teacher and willingness to participate in the study were of paramount importance. For teachers in the experimental groups, the nature and purpose of the study was explained and how to use the case study and puzzle games strategies to teach and achieve learning objectives were adequately demonstrated. Teachers in the control group were not trained by the researcher. However, they were informed on how to use the Conventional Lecture Method Guide to teach topics in the lesson plan which was designed by the researcher and given out to them. Also, each lesson for the seven (7) weeks was discussed with the teachers to ensure they do not divert from the contents to be taught.

\subsection{Administration of Pre-test}

A preliminary quantitative survey of the prevailing achievement in and attitude to leadership value concepts of the selected students was carried out at the four (4) experimental and two (2) control schools before the commencement of the activities by administering the pretest. The administration of the pre-test was carried out using the instrument (CCS) prepared for the study. The selected teachers, research assistants and students in both the control and experimental schools were concurrently involved in specific activities for ten (10) weeks.

\subsection{Experimental group I: The Case Study Strategy}

The steps are as follows:

STEP 1: The teacher introduces the topic.

STEP 2: The teacher exposes students to content of topic to learn

STEP 3: The teacher explains to the students what they are expected to do

STEP 4: The teacher assigns students' to appropriate number of groups (this would be homogeneous but mixed gender grouping) for the case session with a maximum of 5 students in a group.

STEP 5: The teacher presents each group with a case study on the topic and a set of questions at the end of the case.

STEP 6: Each group nominates a session chairman to coordinate group tasks, a secretary and a time keeper (this will be rotational for each session). The chairman is responsible for coordinating the following tasks:

- Reading of cases (must be rotated among members)

- Identification of answers to the questions

- Discussion of answers identified.

STEP 7: The teacher gives students adequate instructions before discussion such as:

- Election of group coordinators should be done through simple open ballot

- Groups are to agree on a uniform answer that will be later presented by the group's chairman.

- Only the person elected as secretary is expected to take notes, others can just underline vital points in the case and the group harmonizes it into a uniform word or sentence.

- Groups could split into sub groups to identify different parts of the answer and re-group to discuss answers found and make it uniform.

- Allow the person who can read more fluently to do the group's reading so that you can save time.

STEP 8: After group discussion, the session chairman presents the group's answer(s)

STEP 9: Teacher relates the case to the topic taught by asking specific questions related to the behavioural objectives set and corrects some of the students' views that might be inconsistent with actual fact. 


\subsection{Experimental Group II: The Puzzle Based Instructional Games Strategy}

The steps are as follows:

STEP 1: The teacher introduces the topic.

STEP 2: The teacher exposes the students to content of the topic to learn.

STEP 3: The teacher explains the rules of the game and its instructions

STEP 4: The teacher explains how to play the game to the students

STEP 5: The teacher divides the class into appropriate number of groups (this would be homogeneous but mixed gender grouping) with not more than five students in a group.

STEP 6: The teacher distributes copies of the puzzle to each group.

STEP 7: Students select members from their group to act as group coordinator and time - keeper/secretary (This would be rotated among group members for each session).

STEP 8: Students start to play the game while teacher observes group activities.

STEP 9: The first group to complete the task appropriately or the group with the highest score from the sum of words after the specified time for the game is reached wins the game.

STEP 9: Post - game activities

Control Group - The Conventional Method

The Teacher:

- Introduces the concept

- Discusses facts or ideas on the concepts in steps

- Gives notes on the concept

- Asks questions in line with behavioural objectives set

- Gives assignment to students.

\section{Data Analyses}

The data collected was analyzed using Analysis of Covariance (ANCOVA) with the pretest scores being used as covariates. The Estimated Marginal Mean (EMM) was employed to determine the magnitude of performances across the groups. The hypotheses were tested at 0.05 level of significance.

\section{Results and Discussion}

$\mathrm{H}_{01}$ : There is no significant main effect of treatment on students' Civic competence in leadership values in social studies and civic education.

Table 1: Summary of 3×3×2 Analysis of Covariance on Students' Civic Competence Level

Dependent variable: Post civic competence

\begin{tabular}{l|c|c|c|c|c|c|}
\hline Source & Type III Sum of Squares & Df & Mean Square & F & Sig. & Partial Eta Squared \\
\hline Corrected Model & $7087.249 a$ & 18 & 393.736 & 4.182 & .000 & .234 \\
Intercept & 17739.990 & 1 & 17739.990 & 188.425 & .000 & .434 \\
Preciviccomp & 12.717 & 1 & 12.717 & .135 & .714 & .001 \\
Tretment & 659.877 & 2 & 329.939 & 3.504 & .032 & .028 \\
Gender & 289.462 & 1 & 289.462 & 3.075 & .081 & .012 \\
Family_Structure & 474.173 & 2 & 237.086 & 2.518 & .083 & .020 \\
Tretment * Gender & 390.126 & 2 & 195.063 & 2.072 & .128 & .017 \\
Tretment * Family_Structure & 2639.606 & 4 & 659.901 & 7.009 & .000 & .102 \\
Gender * Family_Structure & 854.849 & 2 & 427.425 & 4.540 & .012 & .036 \\
Tretment * Gender * Family_Structure & 486.939 & 4 & 121.735 & 1.293 & .119 & .021 \\
Error & 23160.585 & 246 & 94.149 & & & \\
Total & 1409341.000 & 265 & & & & \\
Corrected Total & 30247.834 & 264 & & & & \\
\hline
\end{tabular}

a. $\mathrm{R}$ Squared $=.234$ (Adjusted R Squared $=.178$ ) 
Table 1 reveals that there is a significant main effect of treatment on students' civic competence level $\left(F_{\{2,246\}}=3.50\right.$; $p<0.05 ; \eta^{2}=.03$ ). Therefore, $\mathrm{H}_{0} 1 \mathrm{c}$ is rejected. The magnitude of civic performance in each of the groups of treatment is hereby presented by table 1.1

Table 1.1: Estimated Marginal Means on Students' Civic Competence

\begin{tabular}{|l|c|c|c|}
\hline Variable & N & Mean & Std. Error \\
\hline INTERCEPT & & & \\
Pre-achievement Score & 265 & 71.230 & - \\
Post Achievement Score & 265 & 72.079 & .731 \\
\hline TREATMENT & & & \\
Experimental I (Case Study) & 122 & 70.086 & .978 \\
Experimental II (Puzzle Games) & 80 & 74.624 & 1.406 \\
Control (Conventional method) & 63 & 71.527 & 1.370 \\
\hline
\end{tabular}

Table 1.1 reveals that those exposed to puzzle games (Exp. Group II) had the highest civic competence mean score (74.62), followed by those exposed to conventional method (71.53) while those exposed to case study strategy had the lowest mean score (70.09). In order to discover the source(s) of the significant difference, Scheffe's post-hoc pair-wise comparison was performed and presented in table 1.3

Table 1.3: Scheffe's Pair-wise Comparisons of Civic Competence among the Treatment Groups

\begin{tabular}{|l|c|c|c|c|}
\hline Treatment & Mean & Exp. I & Exp. II & Control \\
\hline Exp. I & 70.086 & & ${ }^{*}$ & \\
\hline Exp. II & 74.624 & ${ }^{*}$ & & $*$ \\
\hline Control & 71.527 & & $*$ & \\
\hline
\end{tabular}
*Implies that there is a significant difference

Table 1.3 reveals that the significant difference exposed by table 1.2 was as a result of the significant difference between:

1. The achievement mean scores of those in experimental I and experimental group II.

2. The achievement mean scores of those in Experimental II and control

\section{Discussions}

Analysis of results obtained from the study showed that the conventional lecture strategy enhanced students' civic competence better than the case study strategy. This finding negates the findings of Rybarczy, Baines, McVey, Thompson and Wilkins (2007) which stated that students who were exposed to the case study strategy demonstrated a better use of higher-order thinking skills (competence) than their counterparts not exposed to the strategy. Nevertheless, just as Rybarczy et al (2007) maintained that more rigorous testing is needed to concretize their finding, this researcher also recommends that further studies be carried out to investigate this disparity.

However, the findings of this study showed that puzzle games strategy enhanced the civic competence of students in leadership value concepts significantly better than the conventional lecture strategy. This finding differs from the findings of Lenhart, Kahne, Middaugh, Macgill, Evans and Vitak (2008) which found out that the quantity of games played was not strongly or consistently related to students' civic outcomes, but some particular qualities of playing games had strong and consistent positive relationship to a range of students' civic outcomes and that of Pagnotti (2012) who found out that in the overall, civic based video games did not enhance civic engagement but there was a significant difference in the mean changes in civic engagement scores of those students who spent more time playing civic based video games than those who did not.

Though, literature has maintained that there is little evidence to support the claim that playing games promotes behaviours or attitudes that undermine civic commitments and that it cannot also be proven that playing games in general, has any link with civic competence, but it could be said that since the findings of Lenhart et al (2008) and Pagnotti (2012) have shown that time spent and particular qualities entrenched in a game are capable of enhancing civic competence, puzzle games enhanced civic competence better because of the time spent (7 weeks) exposing the 
students to it and the qualities of leadership the pattern of the game promoted. Thus the finding of this study is still relevant and can be further researched.

\section{Conclusion}

This study has shown that the active learning strategies of case study and puzzle-based games are effective in enhancing school age children civic competence in leadership value concepts. However, the puzzle games strategy has better potentials at enhancing school age children civic competence better than the case study or conventional lecture method. The active learning activities adopted in the use of these strategies changed the learning orientation of the students not only from boredom to fun but from instruction to discovery which developed in the student's leadership values and competences like cooperation, unity, love, foresight, tolerance, selflessness, hard work, positive use of knowledge, honesty, obedience, respect, fair play, patience and loyalty which are essential to leadership development and sustainability in Nigeria.

Based on the study's findings, it is recommended that puzzle games and case study strategies be further explored in the social studies and civic education classrooms. Also, special consideration as regards length of time for participation should be given to students that will be exposed to puzzle games strategy. The social studies and civic education teachers should also make conscious efforts to utilize the case study and puzzle-based instructional games strategies when teaching leadership value concepts in the classroom. This calls for organization of regular workshops and in-service teacher education programmes for social studies and civic education teachers by government, relevant agencies and professional associations.

\section{References}

Aaron, U.B. (2006). Teaching and assessing in the affective domain: Level I. Retrieved from http://www.aaronbolin.com/pubs/ Affective\%20Domain\%20Level\%20l\%20Workshop\%20Participant.pdf

Adaralegbe, A. (1980). The Nigeria social studies programme: Retrospect and Prospects. In N.E.R.C, Social Studies: Teaching Issues and Problems. Benin: Ethiope Publishing Corporation

Adedoja, G.O \& Fakokunde, J.B. (2010). A survey on the use of instructional games as a method for peace education. Nigerian Journal of Social Studies. XIII (1\&2), $213-224$.

Adesina, A.D.O \& Adeyemi, B.A. (2007). Teaching to achieve social studies values: a case of re-education of teachers. Retrieved from http://www.deta.up.ac.za

Adesoji F.A. (2004). Science and curriculum development: (Lecture note). University of IbadanAdeyemi, B. A. \& Ajibade, Y. A. (2011). The comparative effects of simulation games and

brainstorming instructional strategies on junior secondary school students' achievement in social studies in Nigeria. African Research Review. 5 (3), 64-80.

Afolayan, J.O. \& Afolayan, A.M. (2010). Drug addiction and its academic implications among secondary school students in llorin south local government of Kwara State, Nigeria. Continental Journal of Pharmacology and Toxicology Research. 3. 11-19. Retrieved from http/www.wiloludjournal.com.

Agwagah, U.N.V. (2001). Mathematical games for primary schools. Nsukka: Mike Social Press.

Ajiboye, J.O. (2004). Social studies method II. Ibadan distance learning centre, University of Ibadan.

Alutu, \& Aluedo. (2006). Secondary school students' perception of examination malpractices and examination ethics. Journal of Human Ecology 20 (4), 295-300.

Amosun, P.A. (2002). Three models of group learning strategies, mathematical ability and gender as determinants of secondary school students' learning outcomes in mapwork. (Unpublished Ph.D Thesis) University of Ibadan, Ibadan.

Amosun, P.A \&Ayo - Vaughan, A.F. (2011). The prevailing state of leadership values in Nigeria and its influence on undergraduates' perception of governance. African Journal of Educational Research. 15: (1 \& 2), 13-19

Anochie, I.C. \& Ikpene, E.E. (2001) Prevalence of sexual activity and outcomes among female secondary school students' in PortHarcourt, Nigeria. African Journal of Reproductive Health. 5 (2), 63-67. Retrieved from http://www.jstor.org/stable/3583431

Banerji, P. \& Krishnan, V.R. (2000). Ethical Preferences of Transformational Leaders: An Empirical Investigation. Leadership and Organization Development Journal, 21(8), 405- 413.

Bolarin, T.A. (2005). Education as agent of value clarification and orientation. In valueseducation, Proceedings of the $19^{\text {th }}$ annual congress of the academic of education held at the Lagos state university ,Lagos, November $22-26$.

Bryony, H; Ernesto, V; Daniel, Van Nijlen and Carolyn, B. (2008). Measuring civic competence in Europe. European Commission. Joint Research Centre Institute for the Protection and Security of the Citizen Centre for Research on Lifelong Learning (CRELL) http://www.jrc.ec.europa.eul

Bryony, H; Ernesto, V; Daniel, Van Nijlen and Carolyn, B. (2012). Measuring civic competence in Europe. European Commission. Joint Research Centre Institute for the Protection and Security of the Citizen Centre for Research on Lifelong Learning (CRELL) 
http://www.jrc.ec.europa.eu/

Çam, A \& Geban, O. (2011). Effectiveness of case-based learning instruction on epistemological beliefs and attitudes toward Chemistry. Journal of Science Education and Technology. 20 (1), 26-32.

Childers, C. D. (1996). Using crossword puzzles as an AID to studying sociological concepts. Teaching Sociology. 24 (1), 231-235.

Clegg, A.A. (1991). Games and simulations in social studies education. In hand book of research on social studies teaching and learning. Shaver J.P (Ed). New York: Macmillan Publishing Company.

Crossman, E., and Crossman, S. M. (1983). The crossword puzzle as a teaching tool. Teaching Psychology. 10 (2), 98-99.

Damekaa, U. (2010). Perception of good leadership among the academics in Nigeria: Case of Benue State University, Makurdi. Academic Leadership Journal. 8 (4) Retrieved from http://www.aljRSS.com

Davis, C \&Wilcock, E. (2003). Teaching materials using case studies. The UK Centre for Materials Education. Ashley Printers.

Enakpoya, E. (2009). Prevalence of drug abuse among Nigerian adolescents: implication for Counseling. The Counsellor. 26 (2), 22-25.

Enu, D.B. \& Esu, A.E.O. (2011). Re-engineering values education in Nigerian schools as catalyst for national development. Journal of International Education Studies. 4 (1) 11- 15.

Esen, A.J.A. (1970). Discipline in schools. Journal of the Cross River Educator. 1 (1), 40.

Fagbadebo, O. (2007). Corruption, governance and political instability in Nigeria. African Journal of Political Science and International Relations. 1(2) 28 - 37. Retrieved from htpp://www.academicjournals.org/AJPSIR

Fayombo, G.A. \& Aremu, S. (2000). Drug education and its effects on the educational performance of some adolescents drug abusers in Ibadan, The Counsellor. 18(5), 378-387.

Hecht, J. 2008. Draft: Georgia's behavioral competency framework: behavioral competencies - definitions and behavioral indicators. Retrieved on February 6, 2013 from http://www.slideshare.net/JuliBennette/behavior-indicators

Jansen, J and Christie, P (Eds). (1999). Changing Curriculum Studies on Outcomes based Education in South Africa. Juta: Kenwyn.

Kobiowu, S.V. (2006). The social and academic implications of drug abuse among undergraduates: a case study of the Obafemi Awolowo University, Ile-Ife, Nigeria. International Journal of Psychosocial Rehabilitation. 11(1), 661-68.

Kolawole, C.0.O. (2005). Stakeholders opinion on the role of education in tackling negative values in Nigeria. The Journal of the Nigerian Academy of Education. 14, 71-82.

Kouzes, \& Posner. (2002). The leadership challenge (3rd ed). Jossey-Bass. A Willey Coy. San Francisco, ca. In, Nigerian Institute of Management (Chartered) Journal. 46 (3) 12.

Krishnan, V. (2011). Teachers' assessment of preschoolers' social and emotional competence: does sex of children matter in developmental outcomes? Proceedings of the World Academy of Science, Engineering and Technology, Year 7, Issue 79, pp. 1622-1632

Lambert, L. (2003). Leadership redefined: an evocative context for teacher leadership. Journal of School Leadership and Management. $23(4), 421-430$.

Lombardi, M.M. (2007). Authentic learning for the 21st century: An overview, Educause learning Initiative, Diana G. O. (Ed.). Retrieved from http://www. educause.edu/ir/library/pdf/ELI3009.pdf.

Lenhart, A., Kahne, J., Dean, Middaugh, E., Macgill, A.R., Evans, C and Vitak, J. (2008). Teens, video games and civics: teens' gaming experiences are diverse and include significant social interaction and civic engagement. Pew Research Centre. http://www.pewinternet.org/

Mansaray, A. (1991). TEE 141: Social studies methods. Department of Adult Education, University of Ibadan.

Mazi S.O. (2010). Governance, Economic Planning and Development in Nigeria: The Way Forward. In, Nigerian Institute of Management (Chartered) Journal. 46 (3), 12.

National Council for the Social Studies (2010). National Curriculum Standards for Social Studies: Introduction. Silver Spring, MD. Retrieved from http://www.socialstudies.org/standards/introduction

Nnachi, R.O. (2003). The problems of dropouts and intellectual wastage among male children in the school system within the Igbo speaking states. The Nigerian Educational Psychologists. 1(1), 15-18.

Ogunsanya, M. (1984). Introduction to methodologies of Social Studies. Ibadan: Evans (Nig) Publishers.

Okorodudu, R. \& Okorodudu, G.N. (2004). An overview of conduct problems of the Nigerian Child. Journal of the Nigerian Society for Educational Psychologists. (NICEP), 1 (1) 76-83.

Oni , A.A. (2006). The relationship between levels of education and perception of democratic governance among Nigerian school leavers. Turkish Online Journal of Distance Education. Retrieved from http:// www.tojde.anadolu.edu.tr/tojde21/abs/oni_abs.htm

Oyeniran, S.O. (2010). Responsible leadership for a complex world: importance for students, employers and the international community. Hull University Business School Review. Retrieved fro http://www2.hull.ac.uk/hubs/about/ ision_mission/ responsible_leadership-aspx

Pagnotti, J.C. (2012). The effect of civics-based video games on middle school students' civic engagement (Unpublished Ph.D. Thesis). University of Central Florida Orlando, Florida

Pless, N. \& Maak, T. (2009). Responsible leaders as agents of world benefit: Learning from "Project Ulysses". Journal of Business and Ethics 85: $59-71$.

Popper, M. Mayseless, O. and Castelnovo, O. (2000). Transformational leadership and attachment. Leadership Quarterly, 11(2), 267289.

Rybarczyk, B.J., Baines, A.T., McVey, M., Thompson, J.T \& Wilkins, H. (2007). A case-based approach increases student learning outcomes and comprehension of cellular respiration concepts. Biochemistry and Molecular Biology Education, 35, (3), 181-186. 
Sendur, G. (2012). The effects of case-based learning on freshmen students' chemistry achievement. Energy Education Science and Technology Part B: Social and Educational Studies. 4 (3), 12-15.

Sosik, J.J. (2005). The role of personal values in the charismatic leadership of corporate managers: a model and preliminary field study. Leadership Quarterly, 16(2), 221-244.

South Africa Department of Education. (2001). Values Conference Report. Saamtrek. Department of Education: Pretoria. Author.

Turner, N. Barling, J. Epitropaki, O. Butcher, V. and Milner, C. (2002). Transformational Leadership and Moral Reasoning. Journal of Applied Psychology, 87(2), 304-311.

Waghid, Y. (2004). Compassionate citizenship and education. Perspectives in Education. 22 (1).

Weisskirch, R.S. (2006). An analysis of instructor-created crossword puzzles or students review. College Teaching. 54 (1), 198 - 202. 
